\title{
Species identification of Malayan Gaur, Kedah-Kelantan and Bali cattle using polymerase chain reaction-restricted fragment length polymorphism
}

S.M.N. Romaino', Z.A. Fazly-Ann', S.S. Loo', M.M. Hafiz ${ }^{1}$, M.D. Hafiz ${ }^{1}$, M.I. Iswadi' ${ }^{1}$ P. Kashiani ${ }^{1}$, M.K.A. Rosli ${ }^{2}$, S.M.F. Syed-Shabthar', B.M. Md-Zain ${ }^{2}$ and O. Abas-Mazni ${ }^{1}$

${ }^{1}$ Agro-Biotechnology Institute, Malaysia (ABI), Serdang, Selangor, Malaysia ${ }^{2}$ School of Environmental and Natural Resource Sciences,

Faculty of Science and Technology, Universiti Kebangsaan Malaysia, Bangi, Selangor, Malaysia

Corresponding author: B.M. Md-Zain

E-mail: abgbadd1966@yahoo.com

Genet. Mol. Res. 13 (1): 406-414 (2014)

Received August 9, 2013

Accepted October 16, 2013

Published January 21, 2014

DOI http://dx.doi.org/10.4238/2014.January.21.8

\begin{abstract}
Mitochondrial DNA (mtDNA) is a useful genetic marker that can be used for species identification. The cytochrome b ( Cyt b) gene is a suitable mtDNA candidate gene for use in phylogenetic analyses due to its sequence variability, which makes it appropriate for comparisons at the subspecies, species, and genus levels. This study was conducted to develop a rapid molecular method for species identification of Malayan gaur (Bos gaurus hubbacki), Kedah-Kelantan (KK) (Bos indicus), and Bali (Bos javanicus) cattle in Malaysia. DNA was extracted from blood samples of 8 Malayan gaurs, $30 \mathrm{KK}$, and 28 Bali cattle. A set of both specific and universal primers for the $C y t \mathrm{~b}$ gene were used in PCR amplification. DNA sequences obtained were then analyzed using BioEdit and Restriction Mapper softwares. The PCR products obtained from $C y t \mathrm{~b}$ gene amplification were then subjected to restriction enzyme
\end{abstract}


digestion. The amplification, using both specific and universal primers, produced a 154- and a 603-bp fragment, respectively, in all three species. Two restriction enzymes, NlaIV and SspI, were used to obtain specific restriction profiles that allowed direct identification of Malayan gaur, KK, and Bali cattle. Our findings indicate that all three species can be identified separately using a combination of universal primers and the restriction enzyme $S s p I$.

Key words: Restriction enzymes; Malayan gaur; Kedah-Kelantan; Bali cattle; Seladang

\section{INTRODUCTION}

Bos gaurus hubbacki, Bos javanicus, and Bos indicus are the three major cattle species found in Malaysia, both in the wild and in captivity. B. gaurus hubbacki, or the Malayan gaur, is the largest of all wild cattle, but is currently rarely seen as its population is threatened toward extinction (Yusof, 1981; Conry, 1989). Locally known as Seladang, Malayan gaur are easily recognized by the white stocking on all four legs, its dark brown coat, humped shoulders, and large dewlaps (Medway, 1983). In Malaysia, the Malayan gaur can only be found in the Malay Peninsula (Sahir, 2001). Another wild cattle of Malaysia is B. javanicus. There are two types of $B$. javanicus species; the wild form is known as Banteng, while the domestic form is known as Bali cattle. Both types share similar morphological characteristics, such as white stockings on all four legs, white spots on the back of the body, and a narrow dark stripe along the backbone; the only major difference between the types is their body size (Whitten et al., 1996; Rosli et al., 2011a). The domestic Bali cattle is readily found in Malaysia and Indonesia (Purwantara et al., 2012) as it is commonly bred for beef consumption. B. indicus, or Zebu cattle, is a domestic cattle breed that can be found throughout the world (Hiendleder et al., 2008). The Malaysian Zebu cattle breed is the Kedah-Kelantan (KK) cattle, which can be recognized in several color coats, including brown-black, brown, and yellowish. KK cattle are also readily found in Malaysia as they are an indigenous species used in agricultural and commercialization practices (Rosli et al., 2011a).

Although molecular-based techniques are not the only tools used for species identification, even recently, advances in molecular techniques over the last two decades have allowed the development of authentic and reliable methods for species identification (Nijman et al., 2003; Girish et al., 2005). These techniques are promising and are able to overcome the drawbacks of many conventional methods. The dot-blot technique was the first genetic approach used for the determination of species identity (Ebbehoj and Tomsen, 1991). Currently, polymerase chain reaction (PCR)-based techniques are most commonly used for species identification (Matsunaga et al., 1999; Wan and Fang, 2003; Ang et al., 2011). This is due to their sensitivities, specificities, and capabilities to detect polymorphisms, even among closely related species, up to a single nucleotide differences (Meyer et al., 1995; Lim et al., 2010).

Several identification PCR-derived techniques have been developed to analyze DNA sequences, including random amplified polymorphic DNA, PCR single-strand conformation polymorphism, PCR restriction fragment length polymorphism (PCR-RFLP), DNA hybridization, and nucleotide sequencing, among others (Fairbrother et al., 1998; Lockely and Bardsley, 2002; Rosli et al., 2011b). PCR-RFLP is one of the most popular techniques currently applied in biological research due to its easy application in routine surveys. PCR-RFLP is also able to reveal 
genetic variation among studied species (Dodgson et al., 1997), whether using mitochondrial, nuclear, ribosomal, or chloroplast DNA. Both nuclear and mitochondrial DNA (mtDNA) have been utilized for species identification using the PCR-RFLP method, which is performed alongside restriction enzymes at the targeted sequence. PCR-RFLP analysis requires isolation of the DNA sequence and digestion of fragments with a variety of restriction endonucleases (AbdulMawjood and Bülte, 2002). The resulting fragment patterns are then examined for polymorphisms within and among populations. This technique is also commonly used in forensic applications and in wild species and stock identification (Lenstra et al., 2001; AbdulMawjood and Bülte, 2002). Due to threats toward extinction, the identification of wild cattle is essential for strategy enhancement of conservation and management projects in Malaysia (Md-Zain et al., 2010a).

mtDNA is commonly used because of its highly conserved sequences, maternal inheritance pattern, rapid evolutionary rate, and the fact that it is present in high copy numbers, making it easy to amplify (Irwin et al., 1991; Morlais and Severson, 2002; Mohamad et al., 2012). Moreover, mtDNA lacks recombination and its relatively high mutation rate generates high levels of polymorphism (Hlaing et al., 2009; Vun et al., 2011). Within mtDNA, the cytochrome b (Cyt b), displacement loop (D-loop), 12S rRNA, and 16S rRNA genes have been most widely used for species identification and have been well documented (Meyer et al., 1995; Partis et al., 2000; Ang et al., 2011; Vun et al., 2011). In particular, the Cyt b gene has been used in various studies investigating phylogenetic relationships (Md-Zain et al., $2010 \mathrm{a}, \mathrm{b})$. The sequence variability of the Cyt $\mathrm{b}$ gene makes it suitable for comparing and identifying species in the same genus or the same family (Bowers et al., 1994; Zardoya and Meyer, 2004; Md-Zain et al., 2010a). The present study was designed to investigate the application of the PCR-RFLP technique for the identification of Malayan cattle based on variations in the $C y t$ $\mathrm{b}$ gene among different species, by identifying differences in digestion banding patterns in the studied species. Our focus was to identify the three Malayan cattle species: the Malayan gaur, KK, and Bali cattle. Even though these three types of cattle can be distinguished morphologically, we further demonstrate the potential reliability of adopting molecular techniques for a more substantive identification method of wild and domestic products.

\section{MATERIAL AND METHODS}

\section{Blood collection}

All animals were handled by veterinarians in strict accordance with good animal practices. Blood samples were obtained from 8 Malayan gaurs, 28 Bali cattle, and $30 \mathrm{KK}$ cattle from five different locations (Table 1). All samples were collected in $\mathrm{NH}$ sodium heparin tubes and FTA cards. The blood samples were placed on ice for short-term storage and maintained at $-20^{\circ} \mathrm{C}$ until the DNA extraction processes, while the FTA cards were stored at room temperature.

Table 1. Details of the samples studied.
\begin{tabular}{llcl}
\hline Common name & Scientific name & No. of samples & Location \\
\hline Malayan gaur & B. g. hubbacki & 8 & Wildlife Conservation Centre, Jenderak Selatan, Pahang \\
Bali cattle & B. javanicus & 10 & Felda Farm Products Sdn. Bhd. Palong 16, Negeri Sembilan \\
& & 15 & Jabatan Haiwan \& Perusahaan Ternak, Tawau, Sabah \\
Kedah-Kelantan (KK) & B. indicus & 3 & National Biotechnology Veterinary Institute (IBVK), Jerantut, Pahang \\
& & 18 & Jukimas Sepang, Negeri Sembilan \\
& 12 & National Biotechnology Veterinary Institute (IBVK), Jerantut, Pahang \\
\hline
\end{tabular}




\section{DNA extraction}

Total genomic DNA was extracted using the QIAGEN DNeasy Blood \& Tissue Kit according to the protocol provided by the manufacturer. The extracted DNA was stored at $-20^{\circ} \mathrm{C}$.

\section{PCR amplification}

The specific primer used for PCR amplification was designed based on the mitochondrial Cyt b gene of a B. gaurus sequence obtained from GenBank (DQ 459331). The universal primers used to amplify the mitochondrial $C y t$ b gene were obtained from Lenstra et al. (2001) (Table 2). The optimized PCR protocol included a final reaction mixture that comprised 1X PCR buffer, $2.0 \mathrm{mM} \mathrm{MgCl}, 0.2 \mathrm{mM}$ dNTPs, $0.2 \mu \mathrm{M}$ forward primers (5'-AAGCTTGTGACA GATAGAACGAT-3') and reverse primers (5'-CAAGCTGTCTAGAATTCAGGGA-3'), 0.1 U Taq DNA polymerase, 50 ng genomic DNA, and autoclaved Milli-Q water in a total volume of $25 \mu \mathrm{L}$. PCR amplification was performed in a Biometra Thermalcycler with initial denaturation at $94^{\circ} \mathrm{C}$ for $4 \mathrm{~min}$, followed by 30 cycles of denaturation at $94^{\circ} \mathrm{C}$ for $1 \mathrm{~min}$, annealing at $55^{\circ} \mathrm{C}$ for $1 \mathrm{~min}$, and extension at $72^{\circ} \mathrm{C}$ for $1 \mathrm{~min}$. A final extension at $72^{\circ} \mathrm{C}$ for 8 min was included before a cooling step at $4^{\circ} \mathrm{C}$. Desired DNA bands were observed on $2.0 \%$ agarose gel containing ethidium bromide, and were visualized and photographed with the Gel Documentation System (Chemilmager ${ }^{\text {TM }}$ 4400, Alpha Innotech).

Table 2. Details of specific primers used in this study.

\begin{tabular}{llc}
\hline Primer & Sequence $\left(5^{\prime}-3^{\prime}\right)$ & Size (bp) \\
\hline Specific primers & Forward: AGCAACCCTTACCCGATTCT & 154 \\
& Reverse: GTAGGGGTGGAATGGGATTT & 154 \\
Universal primers & Forward: AAG CTT GTG ACA GAT AGA ACG AT & 603 \\
& Reverse: CAA GCT GTC TAG AAT TCA GGG A & 603 \\
\hline
\end{tabular}

\section{DNA purification and sequencing}

Purification of the PCR products was carried out using the Wizard SV Gel and PCR Clean-Up System (Promega) according to manufacturer instructions. The purified PCR products were then sent directly to the sequencing service company, First Base Sdn. Bhd. (Malaysia), to be sequenced together with the above primers.

\section{Sequence analysis}

Pairwise alignment of both complimentary forward and reverse primer sequences were analyzed using the BioEdit Version 7 software. After analyzing $C y t \mathrm{~b}$ consensus sequences of the three species, restriction maps were generated using the Restriction Mapper software. Two restriction enzymes, NlaIV and $S s p$ I (Fermentas) were selected and considered to be informative as they could generate different band patterns for direct identification of Malayan gaur, KK, and Bali cattle. 


\section{RFLP analysis}

PCR products resulting from amplification of the $C y t \mathrm{~b}$ gene were subjected to restriction enzyme digestion. The reaction mixture was prepared by mixing $10 \mu \mathrm{L}$ amplified PCR products with $1 \mu \mathrm{L}$ of each restriction enzyme and $2 \mu \mathrm{L}$ buffer. The total volume was adjusted to $30 \mu \mathrm{L}$ by adding autoclaved Milli-Q water, which was then incubated at $37^{\circ} \mathrm{C}$ for $5 \mathrm{~min}$ under conditions recommended by the enzyme manufacturer. Digested products were analyzed on agarose gel.

\section{RESULTS}

DNA from all studied cattle samples were extracted, amplified, and sequenced successfully. The specific and universal primers used in PCR amplification generated fragments of approximately 154 and $603 \mathrm{bp}$, respectively (Figure 1). Prior to sequence analysis, the Basic Local Alignment Search Tool (BLAST) was used to compare the obtained sequences with those in databases and to calculate the statistical significance of matches. All DNA sequences matched DNA sequences of the genus Bos contained in the online database.

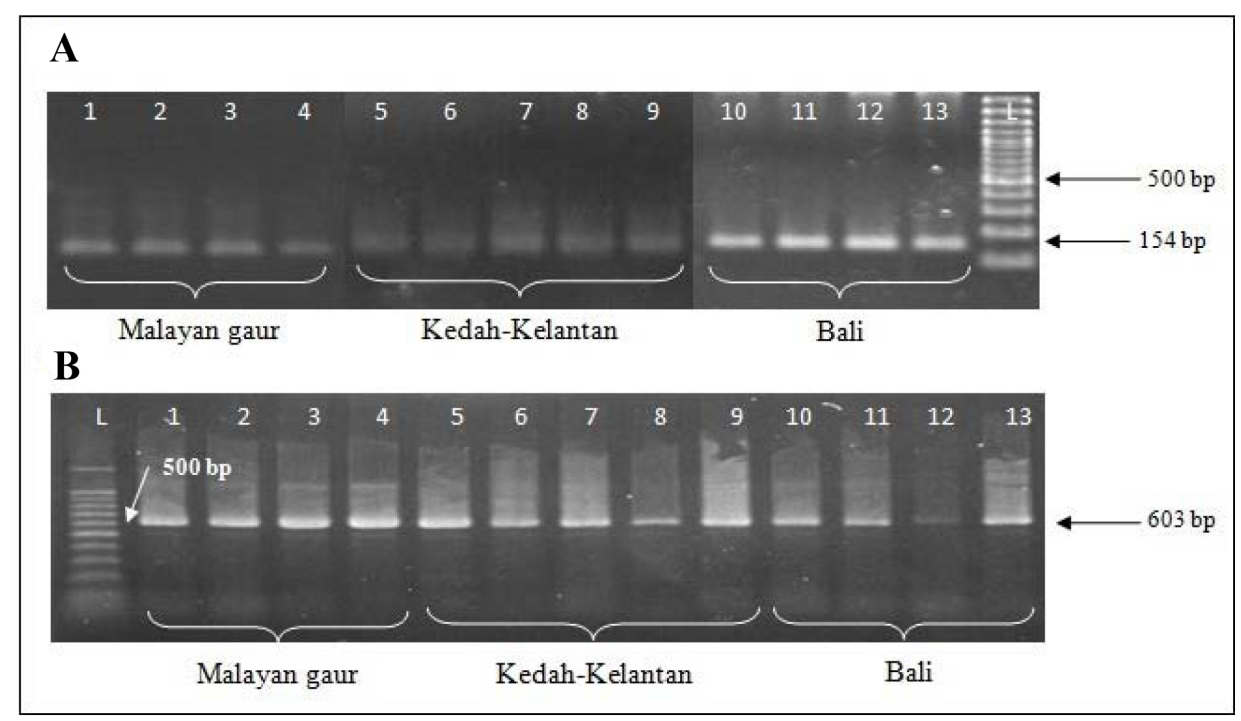

Figure 1. PCR amplification of the $C y t \mathrm{~b}$ gene using specific primers (A) produced a 154-bp fragment and universal primers (B) produced a 603-bp fragment for Malayan gaur, Kedah-Kelantan and Bali cattle as indicated by a 100-bp DNA ladder (L).

After analyzing the sequence results of the 154- and 603-bp fragments, a few intraspecific differences were excluded, and restriction maps were constructed to detect and differentiate the species. The restriction enzyme NlaIV produced two fragments of 56 and 98 bp for all three species. $S s p$ I also produced two fragments for Malayan gaur and Bali cattle species, but of different sizes; 454 and 125 bp for Malayan Gaur and 472 and $107 \mathrm{bp}$ for Bali cattle. However, $S s p$ I did not digest at any position for KK cattle samples (Figure 2). Based on 
Restriction Mapper, the restriction enzyme $S s p$ I did not cut at any position in KK when PCR amplification was performed using universal primers. Thus, $S s p$ I did not digest at any position when RFLP was performed. The fragment sizes after digestion with restriction enzymes NlaIV and $S s p$ I are summarized in Table 3.

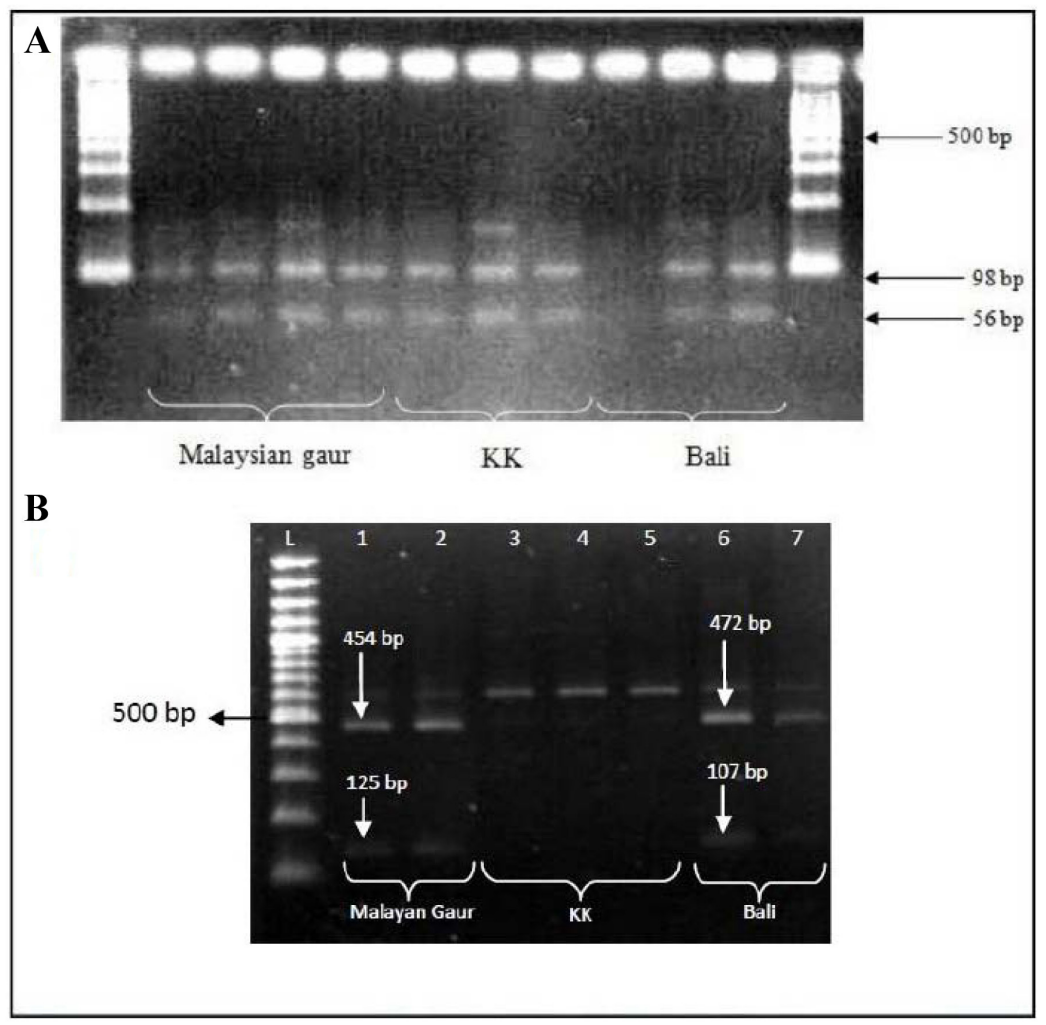

Figure 2. RFLP digestions of the $C y t \mathrm{~b}$ gene. PCR amplicons were subjected to restriction analysis; A. NlaIV enzyme resulted in 56- and 98-bp fragments in all three species. B. SspI enzyme resulted in 125- and 454-bp fragments in Malayan Gaur (lane 1), 107- and 472-bp fragments in Bali cattle (lane 6), but did not digest in KedahKelantan (KK) (lane 3) as indicated by a 100-bp DNA ladder (L).

Table 3. Differences of fragment size after digestion by restriction enzymes for the $C y t \mathrm{~b}$ gene.

\begin{tabular}{lcccc}
\hline Primer & Restriction enzymes & \multicolumn{2}{c}{ Species } \\
\cline { 3 - 5 } & & Malayan gaur & Kedah-Kelantan & Bali \\
\hline Specific primer & NlaIV & 56 and 98 bp & 56 and 98 bp & 56 and 98 bp \\
Universal primer & Ssp & 454 and 125 bp & - & 472 and 107 bp \\
\hline
\end{tabular}

\section{DISCUSSION}

This study used the PCR-RFLP method with the mtDNA Cyt b gene for species identification of Malayan gaur, KK, and Bali cattle. The results showed evidence that our 
molecular markers were associated with genetic similarities among the three studied species. Prior to validating uncontaminated DNA during extraction, we performed PCR amplification of the $C y t \mathrm{~b}$ gene by using both specific and universal primers, and all samples produced DNA fragments with expected lengths for Malayan Gaur, KK, and Bali cattle (Lenstra et al., 2001). The restriction enzyme NlaIV was used to digest $154 \mathrm{bp}$ of the amplified PCR fragment, which resulted in the same restriction pattern profiles, with a size of 56 and $98 \mathrm{bp}$, in all three species. These digestions indicated that the restriction enzyme NlaIV cannot reveal variations among these three species that were PCR-amplified using specific primers. On the other hand, the restriction enzyme $S s p$ I was used to digest $603 \mathrm{bp}$ of the PCR fragment that was amplified using the universal primer. Ss $\mathrm{I}$ produced two digested fragments, with the sizes of 454 and $125 \mathrm{bp}$ in Malayan gaur and sizes of 472 and $107 \mathrm{bp}$ in Bali cattle. However, SspI did not digest at any position in KK cattle. These different length digestions demonstrated that the restriction enzyme $S s p$ I is a very appropriate enzyme to be used for identification of these three cattle species. Based on these results, the restriction digestion pattern obtained from cutting sequences of the $C y t$ b gene amplified by the universal primer could be a more reliable method of species identification compared to digesting the DNA fragments amplified by the specific primer.

In our study, results showed that the three Malayan cattle species could be differentiated by amplification of the $C y t$ b gene using a universal primer together with the restriction enzyme SspI. The restriction digestion pattern obtained from a combination of PCR amplification and restriction enzymes for RFLP analysis proved to be a suitable marker tool for the identification of these three species of cattle (Lenstra et al., 2001; AbdulMawjood and Bülte, 2002). Therefore, this study revealed the significant role that PCR-based techniques can play in species identification, and emphasizes the importance of choosing the right genes with suitable variation rates (Brown, 1983; Wolf et al., 1999). This method was successfully used to type both Malaysian wild and domestic cattle, and has previously been used in species identification of game and domestic meats (Prado et al., 2007; Fajardo et al., 2009; Wang et al., 2010; Chen et al., 2010).

In conclusion, PCR-RFLP of $C y t \mathrm{~b}$ gene fragments that were amplified using universal primers is an effective technique for identification of Malayan gaur, Kedah-Kelantan, and Bali cattle. These species could be directly identified by using the restriction enzyme NlaIV, which will produce the same digestion profile among the three species. For discrimination among the three species, the restriction enzyme $S s p$ I can be used instead, which produces distinct digestion profiles. However, further studies and investigations should focus on designing species-specific primers and/or probes for direct diagnosis, and more DNA regions should be analyzed in order to provide polymorphic sequence data for differentiating these animals.

\section{ACKNOWLEDGMENTS}

We would like to express our sincere appreciation to the Ministry of Science, Technology \& Innovation (MOSTI, Malaysia), the Agro-Biotechnology Institute (ABI), and Universiti Kebangsaan Malaysia (UKM) for their continuous support throughout this research process. We also thank the Department of Wildlife and National Parks of Peninsular Malaysia, National Biotechnology Veterinary Institute, Jabatan Haiwan \& Perusahaan Ternak, Tawau, 
Sabah and Felda Farm Products Sdn. Bhd., for providing genetic samples. Research supported by a grant under project \#06-05-ABI-AB003 from the Agro-Biotechnology Institute, Malaysia (ABI) and grant \#02-01-02-SF0762 for the publication process.

\section{REFERENCES}

AbdulMawjood A and Bülte M (2002). Identification of ostrich meat by restriction fragment length polymorphism (RFLP) analysis of cytochrome $b$ gene. J. Food Sci. 67: 1688-1691.

Ang KC, Leow JW, Yeap WK, Hood S, et al. (2011). Phylogenetic relationships of the Orang Asli and Iban of Malaysia based on maternal markers. Genet. Mol. Res. 10: 640-649.

Bowers N, Stauffer JR and Kocher TD (1994). Intra- and interspecific mitochondrial DNA sequence variation within two species of rock-dwelling cichlids (Teleostei: Cichlidae) from Lake Malawi, Africa. Mol. Phylogenet. Evol. 3: 75-82.

Brown WN (1983). Evolution of Animal Mitochondrial. Sinauer, Sunderland.

Chen SY, Liu YP and Yao YG (2010). Species authentication of commercial beef jerky based on PCR-RFLP analysis of the mitochondrial 12S rRNA gene. J. Genet. Genomics 37: 763-769.

Conry PJ (1989). Gaur Bos gaurus and development in Malaysia. Biol. Conserv. 49: 47-65.

Dodgson JB, Cheng HH and Okimoto R (1997). DNA marker technology: a revolution in animal genetics. Poult. Sci. 76: 1108-1114.

Ebbehoj KF and Thomsen PD (1991). Differentiation of closely related species by DNA hybridization. Meat Sci. 30 : 359-366.

Fairbrother KS, Hopwood AJ, Lockley AK and Bardsley RG (1998). The actin multigene family and livestock speciation using the polymerase chain reaction. Anim. Biotechnol. 9: 89-100.

Fajardo V, González I, Dooley J, Garret S, et al. (2009). Application of polymerase chain reaction-restriction fragment length polymorphism analysis and lab-on-a-chip capillary electrophoresis for the specific identification of game and domestic meats. J. Sci. Food Agric. 89: 843-847.

Girish PS, Anjaneyulu AS, Viswas KN, Shivakumar BM, et al. (2005). Meat species identification by polymerase chain reaction-restriction fragment length polymorphism (PCR-RFLP) of mitochondrial 12S rRNA gene. Meat Sci. 70: 107-112.

Hiendleder S, Lewalski H and Janke A (2008). Complete mitochondrial genomes of Bos taurus and Bos indicus provide new insights into intra-species variation, taxonomy and domestication. Cytogenet. Genome Res. 120: 150-156.

Hlaing T, Tun-Lin W, Somboon P, Socheat D, et al. (2009). Mitochondrial pseudogenes in the nuclear genome of Aedes aegypti mosquitoes: implications for past and future population genetic studies. BMC Genet. 10: 11.

Irwin DM, Kocher TD and Wilson AC (1991). Evolution of the cytochrome $b$ gene of mammals. J. Mol. Evol. 32: 128-144.

Lenstra JA, Buntjer JB and Janssen FW (2001). On the origin of meat - DNA techniques for species identification in meat products. Vet. Sci. Tomorrow 2: 1-15.

Lim LS, Ang KC, Mahani MC, Shahrom AW, et al. (2010). Mitochondrial DNA Polymorphism and Phylogenetic Relationships of Proto Malays in Peninsular Malaysia. J. Biol. Sci. 10: 71-83.

Lockely AK and Bardsley RG (2002). Intron variability in an actin gene can be used to discriminate between chicken and turkey DNA. Meat Sci. 61: 163-168.

Matsunaga T, Chikuni K, Tanabe R, Muroya S, et al. (1999). A quick and simple method for the identification of meat species and meat products by PCR assay. Meat Sci. 51: 143-148.

Md-Zain BM, Lee SJ, Lakim M, Ampeng A, et al. (2010a). Phylogenetic position of Tarsius bancanus based on partial Cytochrome b DNA sequences. J. Biol. Sci. 10: 348-354.

Md-Zain BM, Mohamad M, Ernie-Muneerah MA, Ampeng A, et al. (2010b). Phylogenetic relationships of Malaysian monkeys, Cercopithecidae, based on mitochondrial cytochrome c sequences. Genet. Mol. Res. 9: 1987-1996.

Medway L (1983). Wild Mammals of Malaya (Peninsular Malaysia) and Singapore. Oxford University Press, Kuala Lumpur.

Meyer R, Hofelein C, Luthy J and Candrian U (1995). Polymerase chain reaction-restriction fragment length polymorphism analysis: a simple method for species identification in food. J. AOAC Int. 78: 1542-1551.

Mohamad K, Olsson M, Andersson G, Purwantara B, et al. (2012). The origin of Indonesian cattle and conservation genetics of the Bali cattle breed. Reprod. Domest. Anim. 47 (Suppl 1): 18-20.

Morlais I and Severson DW (2002). Complete mitochondrial DNA sequence and amino acid analysis of the cytochrome C oxidase subunit I (COI) from Aedes aegypti. DNA Seq. 13: 123-127.

Nijman IJ, Otsen M, Verkaar EL, de Ruijter C, et al. (2003). Hybridization of Banteng (Bos javanicus) and Zebu (Bos 
indicus) revealed by mitochondrial DNA, satellite DNA, AFLP and microsatellites. Heredity 90: 10-16.

Partis L, Croan D, Guo Z, Clark R, et al. (2000). Evaluation of a DNA fingerprinting method for determining the species origin of meats. Meat Sci. 54: 369-376.

Prado M, Calo-Mata P, Villa TG, Cepeda A, et al. (2007). Co-amplification and sequencing of a cytochrome b fragment affecting the identification of cattle in PCR-RFLP food authentication studies. Food Chem. 105: 436-442.

Purwantara B, Noor RR, Andersson G and Rodriguez-Martinez H (2012). Banteng and Bali cattle in Indonesia: status and forecasts. Reprod. Domest. Anim. 47 (Suppl 1): 2-6.

Rosli MK, Zakaria SS, Syed-Shabthar SM, Zainal ZZ, et al. (2011a). Phylogenetic relationships of Malayan gaur with other species of the genus Bos based on cytochrome $b$ gene DNA sequences. Genet. Mol. Res. 10: 482-493.

Rosli MK, Zamzuriada AS, Syed-Shabthar SM, Mahani MC, et al. (2011b). Optimization of PCR conditions to amplify Cyt $b$, COI and 12S rRNA gene fragments of Malayan gaur (Bos gaurus hubbacki) mtDNA. Genet. Mol. Res. 10: 2554-2568.

Sahir O (2001). Breeding performance of the Malaysian captive gaur. J. Wildl. Parks 19: 25-32.

Vun VF, Mahani MC, Lakim M, Ampeng A, et al. (2011). Phylogenetic relationships of leaf monkeys (Presbytis; Colobinae) based on cytochrome b and 12S rRNA genes. Genet. Mol. Res. 10: 368-381.

Wan QH and Fang SG (2003). Application of species-specific polymerase chain reaction in the forensic identification of tiger species. Forensic Sci. Int. 131: 75-78.

Wang Q, Zhang X, Zhang HY, Zhang J, et al. (2010). Identification of 12 animal species meat by T-RFLP on the 12S rRNA gene. Meat Sci. 85: 265-269.

Whitten T, Soeriaatmadja RE and Afiff SA (1996). The Ecology of Java and Bali. Vol. II. Periplus Editions (HK) Ltd., Singapore.

Wolf C, Rentsch J and Hubner P (1999). PCR-RFLP analysis of mitochondrial DNA: a reliable method for species identification. J. Agric. Food Chem. 47: 1350-1355.

Yusof E (1981). Seladang (Bos gaurus hubbacki) in Malaysia. Unpublished Report by the Department of Wildlife and National Parks, Kuala Lumpur.

Zardoya R and Meyer A (2004). Molecular Evidence on the Origin of and the Phylogenetic Relationships Among the Major Groups of Vertebrates. In: Evolution from Molecules to Ecosystems (Moya A and Font E, eds.). Oxford University Press, Inc., New York, 209-217. 